\title{
STUDI EVALUASI PELAKSANAAN KEBIJAKAN SERTIFIKASI GURU DI KEMENTERIAN AGAMA
}

\author{
Kamal Fuadi ${ }^{1 *}$, Bedjo Sujanto ${ }^{2}$, Kamaluddin ${ }^{3}$ \\ 1Universitas Negeri Jakarta \\ 1J1.Rawamangun Muka, RT.11/RW.14, Pulo Gadung, Jakarta Timur, Jakarta 13220, Indonesia \\ * Corresponding Author. Email: notkamal@gmail.com
}

\begin{abstract}
Abstrak
Penelitian ini bertujuan untuk mengevaluasi (1) lingkungan strategis implementasi kebijakan, (2) proses implementasi kebijakan, dan (3) hasil implementasi kebijakan sertifikasi guru di Kementerian Agama RI. Penelitian menggunakan pendekatan kualitatif dengan model evaluasi Countenance yang dikembangkan oleh Stake. Lingkungan strategis implementasi kebijakan sertifikasi guru di Kementerian Agama RI cukup mendukung keterlaksanaan dan pencapaian hasil kebijakan namun masih ditemui beberapa kelemahan dan kendala yaitu peserta mengundurkan diri, belum ada rencana induk pengembangan, belum ada evaluasi diri dan penjaminan mutu kelembagaan LPTK. Kementerian Agama RI melakukan proses pengawasan dan evaluasi namun kurang terdokumentasikan sehingga proses tindak lanjut tidak dilaksanakan. Implementasi kebijakan menghasilkan lulusan guru profesional namun terdapat kelemahan dan kendala yang menyebabkan banyaknya peserta yang mengundurkan diri dan tidak lulus. Pada angkatan I seluruh peserta sertifikasi guru lulus. Pada angkatan II dari 947 peserta jumlah yang lulus sebanyak 945 (99,79\%) dan yang tidak lulus sebanyak 2 $(0,21 \%)$.
\end{abstract}

Kata kunci: kebijakan, evaluasi, guru, sertifikasi

\section{EVALUATION OF IMPLEMENTATION OF TEACHER CERTIFICATION POLICY IN THE MINISTRY OF RELIGIOUS AFFAIRS}

\begin{abstract}
This study aims to evaluate (1) the strategic environment of the policy implementation; (2) the process of the policy implementation; and (3) the results of the policy implementation of teacher certification on the Ministry of Religious Affairs (MORA). The research method was a qualitative evaluation approach based on a model of evaluation developed by Stake. The strategic environment in the MORA is sufficient to support the implementation and achievement of the policy result although there are still weaknesses and obstacles follows that the participants resign, there is no PPG development master plan, no selfevaluation, and institutional quality assurance. The MORA has conducted a process of monitoring and evaluation although it is not documented so that the follow-up process is not implemented. Implementation of the policy shows the results of graduates of professional teachers despite the weaknesses and obstacles that caused many participants who resigned and did not pass. In the first batch of all teacher, certification participants passed all. In the second batch of 947 participants, the number passed as 945 (99.79\%) and who did not pass as much as 2 (0.21\%).
\end{abstract}

Keywords: policy, evaluation, teacher, certification

Permalink/DOI: http://dx.doi.org/10.21831/amp.v6i2.20714 


\section{Pendahuluan}

Guru adalah pendidik profesional yang wajib memiliki sertifikat pendidik, kualifikasi akademik, kompetensi, sehat jasmani dan rohani, serta memiliki kemampuan untuk mewujudkan tujuan nasional sebagaimana dituangkan dalam UndangUndang Nomor 14 Tahun 2005 tentang Guru dan Dosen (Depdiknas, 2005). Sertifikat pendidik dapat diperoleh melalui program sertifikasi yang dilaksanakan dalam bentuk Porto Folio (PF), Pemberian Sertifikat Pendidik secara Langsung (PSPL), Pendidikan Profesi Guru (PPG) atau Pendidikan dan Latihan Profesi Guru (PLPG) yang diselenggarakan oleh perguruan tinggi yang telah memenuhi syarat sebagai Lembaga Pendidikan Tenaga Kependidikan (LPTK).

Sertifikasi penting untuk membentuk kompetensi pedagogik, kompetensi kepribadian, kompetensi sosial, dan kompetensi profesional yang dibuktikan dengan sertifikat pendidik yang diperoleh melalui sertifikasi guru di LPTK. Selain meningkatkan kompetensi, sertifikasi guru juga akan meningkatkan kesejahteraan guru berupa pemberian tunjangan profesi bagi guru yang memiliki sertifikat pendidik dan memenuhi persyaratan lain sesuai dengan ketentuan yang berlaku. Tunjangan tersebut diberikan baik bagi guru yang berstatus Pegawai Negeri Sipil (PNS) maupun bagi guru yang berstatus bukan PNS (swasta).

Peneliti secara khusus menyoroti sertifikasi guru melalui jalur PPG dalam Jabatan di Kementerian Agama. Program sertifikasi guru melalui Jalur PPG dalam Jabatan di Kementerian Agama telah berjalan sejak tahun 2012. Program ini sebenarnya telah dirancang sejak lama. Bahkan pada tahun 2009 dan 2010, Kementerian Agama telah mengalokasikan anggaran pelaksanaan PPG namun program ini tidak dapat dilaksanakan karena belum memiliki payung hukum (Badruzzaman, 2016, pp. 141-156).

Pada tahun 2011, Kementerian Agama telah memiliki legalitas menyelenggarakan program sertifikasi guru dengan dikeluarkannya Keputusan Menteri Pendidikan dan Kebudayaan Republik Indonesia Nomor 224/P/2011 Tentang Penetapan Lembaga
Pendidikan Tenaga Kependidikan Penyelenggara Pendidikan Profesi Guru bagi Guru dalam Jabatan di Lingkungan Kementerian Agama. LPTK di lingkungan Kementerian Agama yang ditunjuk berdasarkan surat tersebut berjumlah 24 LPTK.

Program PPG belum dilaksanakan di Kementerian Agama di tahun 2011. Kebijakan PPG di Kementerian Agama baru dilaksanakan tahun 2012 dengan kewenangan: (1) menyelenggarakan pendidikan bagi guru-guru Pendidikan Agama Islam (PAI), (2) menyelenggarakan PPG untuk program studi mata pelajaran rumpun PAI, 3) beberapa Perguruan Tinggi Agama Islam Negeri (PTAIN) diberi peluang untuk mempersiapkan PPG mata pelajaran umum, dan (4) penyelenggaraan PPG $100 \%$ masih dibiayai negara.

Meski LPTK yang ditunjuk berdasarkan SK Nomor 214/P/2011 sebanyak 24, Kementerian Agama melakukan screening kembali dan menetapkan sebanyak 13 LPTK saja yang dinyatakan siap menyelenggarakan PPG berdasarkan Surat Keputusan Direktur Jenderal Pendidikan Islam Nomor 1909/2012 tentang Penetapan Perguruan Tinggi Agama Islam (PTAI) Penyelenggara Program Pendidikan Profesi Guru (PPG) bagi Guru RA/Madrasah dan Kuota Masing-Masing Tahun 2012. LPTK tersebut yaitu Universitas Islam Negeri (UIN) Syarif Hidayatullah Jakarta, UIN Sunan Kalijaga Yogyakarta, UIN Syarif Kasim Riau, UIN Sunan Gunung Djati Bandung, UIN Alauddin Makassar, UIN Sunan Ampel Surabaya, UIN Ar-Raniry Aceh, Institut Agama Islam Negeri (IAIN) Raden Fatah Palembang, IAIN Sumatera Utara, IAIN Walisongo Semarang, IAIN Raden Intan Lampung, IAIN Mataram, dan Sekolah Tinggi Agama Islam Negeri (STAIN) Jember.

Pada 2014/2015 Direktorat Pendidikan Tinggi Islam Kementerian Agama dengan seluruh LPTK Penyelenggara PPG bersepakat untuk tetap melanjutkan PPG dalam jabatan mengingat jumlah guru madrasah yang belum tersertifikasi masih berjumlah 168.000 orang. Dari jumlah tersebut, sebanyak 38.000 orang guru akan mengikuti program sertifikasi guru melalui jalur PL- 
PG. Namun demikian pada tahun tersebut anggaran yang sedianya diperuntukkan untuk melanjutkan program PPG kemudian dialihkan untuk program PLPG sehingga program PPG harus terhenti sementara.

Direktorat Pendidikan Tinggi Islam menyatakan bahwa LPTK Penyelenggara dianggap telah berhasil menyelenggarakan program PPG dalam jabatan. Namun demikian, terdapat beberapa permasalahan, salah satunya berkaitan dengan kepesertaan. Banyak peserta yang mengundurkan diri dari program karena yang bersangkutan kedapatan telah mengikuti PLPG.

Selain peserta yang mengundurkan diri, terdapat pula peserta yang masih melakukan aktivitas pembelajaran di sekolah/ madrasah tempat mengajar selama mengikuti program PPG. Beberapa peserta program PPG di beberapa LPTK tidak lulus karena terkendala sulitnya mendapatkan SK dari sekolah dan madrasah tempat mengajar serta Dinas Pendidikan Kabupaten/Kota. Permasalahan mengenai kepesertaan juga terdapat pada Nomor Induk Mahasiswa (NIM) yang tidak didapatkan oleh calon peserta yang dinyatakan lulus dan diterima dalam program PPG yang mengakibatkan adanya kesulitan-kesulitan yang dialami peserta dalam mengakses fasilitas yang dimiliki oleh LPTK. Pada saat penerbitan Nomor Registrasi Guru (NRG), peserta program PPG yang telah lulus tidak langsung mendapatkan NRG yang berakibat pada keterlambatan verifikasi data yang berujung pada terlambatnya pembayaran tunjangan sertifikasi. Persoalan lain yaitu belum adanya rencana induk pengembangan program PPG yang disusun bersama oleh LPTK dan pemerintah dan belum adanya evaluasi diri dan penjaminan mutu kelembagaan LPTK sebagai penyelenggara program PPG.

Direktur Pendidikan Tinggi Islam Kementerian Agama sendiri mengakui jika masih ada beberapa kendala yang terdapat dalam penyelenggaraan program PPG dalam Jabatan antara lain: (1) LPTK yang tidak confident dengan output PPG, (2) LPTK yang cenderung tunduk pada keinginan peserta PPG, (3) Peserta PPG mengundurkan diri,
(4) Keterlambatan penerbitan SK NRG, dan

5) Kebijakan yang kurang berpihak.

Beberapa penelitian mengenai hasil dari implementasi kebijakan sertifikasi guru menunjukkan bahwa sertifikasi guru hanya memiliki kontribusi yang sedikit terhadap peningkatan kualitas pendidikan (Utami, 2015, pp. 471-481). Bahkan disebutkan bahwa hasil dari kebijakan sertifikasi guru masih belum jelas apakah menunjukkan peningkatan dalam pencapaian pembelajaran peserta didik atau tidak. Guru sendiri cenderung tidak menunjukkan performa yang lebih baik setelah mengikuti sertifikasi guru (Kusumawardhani, 2017, pp. 590-617).

Pada implementasi kebijakan, proses pengawasan, evaluasi, dan pembuatan laporan kegiatan masih belum terlaksana. Pedoman pelaksanaan sertifikasi guru juga masih banyak yang belum dilaksanakan (Yusuf, Bekti, \& Sukarno, 2017, pp. 43-50). Pelaksanaan sertifikasi guru PAI walaupun sudah berjalan sesuai pedoman namun masih mengalami kendala dalam sosialisasi dan pemberian tunjangan yang sering terlambat (Qowaid, 2015, pp. 446-462).

Beberapa kendala dan kekurangan yang dihadapi dalam pelaksanaan sertifikasi guru tersebut bahkan dinilai oleh Pengurus Besar Persatuan Guru Republik Indonesia (PB PGRI) sebagai bentuk kegagalan pemerintah dalam melaksanakan amanat UU Nomor 14 Tahun 2005 tentang Guru dan Dosen (Depdiknas, 2005). PB PGRI menyebutkan, sebagaimana disebutkan dalam UU, paling lambat 10 tahun sejak UU ditetapkan atau pada 2015, semua guru sudah berkualifikasi pendidikan S1 atau D-IV dan dilengkapi dengan sertifikat pendidik. Kementerian Agama pernah menargetkan pada 2014 sertifikasi guru madrasah telah selesai.

Situasi di atas mengindikasikan bahwa penelitian terhadap kebijakan sertifikasi guru melalui PPG dalam jabatan di lingkungan Kementerian Agama perlu dilakukan untuk mengetahui permasalahan kebijakan dalam lingkup yang dapat dibatasi sekaligus mengidentifikasi aspek-aspek yang dapat dikembangkan menjadi kekuatan kebijakan ke depan dengan memperbaiki ke- 
lemahan yang ditemui. Hal ini mendorong peneliti untuk melakukan penelitian lebih lanjut mengenai kebijakan sertifikasi guru melalui jalur PPG dalam jabatan di lingkungan Kementerian Agama. Studi mengenai kebijakan ini digunakan untuk menelaah lebih jauh mengenai bagaimana kebijakan direncanakan dan diimplementasikan

\section{Metode Penelitian}

Penelitian ini menggunakan pendekatan studi kasus dengan model evaluasi Countenance yang dikembangkan Stake dengan metode kualitatif. Pendekatan studi kasus adalah pendekatan yang banyak ditemukan dalam banyak bidang khususnya evaluasi di mana peneliti mengembangkan analisis mendalam atas suatu kasus yang dibatasi oleh waktu dan aktivitas peneliti (Creswell, 2008, p. 19). Dalam konteks kebijakan, Yin sebagaimana dikutip Ann Crabb dan Pieter Leroy menyatakan bahwa studi kasus dapat menjelaskan mengenai bagaimana dan mengapa suatu kebijakan dapat terjadi (Crabb \& Leroy, 2008, pp. 59-64).

Dalam melakukan evaluasi implementasi kebijakan sertifikasi guru melalui jalur PPG dalam jabatan di Kementerian Agama RI, peneliti terlebih dahulu mengidentifikasi 3 tahapan penting sesuai model evaluasi Countenance yang dikembangkan oleh Stake yaitu (1) antecedent (tahapan awal), (2) transaction (tahapan proses), dan (3) outcome (hasil).

Evaluasi implementasi kebijakan sertifikasi guru melalui jalur PPG dalam jabatan di Kementerian Agama RI dilakukan berdasarkan pada perbandingan antara data empiris tentang apa yang sebenarnya terjadi (observation) serta kesesuaiannya (congruence) dengan tujuan (intens). Hasil perbandingan tersebut digunakan dalam penilaian (judgements) guna pengambilan keputusan pada setiap komponen yang dievaluasi. Hal demikian juga dilakukan untuk mengetahui keterkaitan antar komponen dilakukan analisis kontingensi.

\section{Hasil Penelitian dan Pembahasan}

Komponen Antecendents

Komponen antecedents adalah kondisi awal lingkungan yang dipersyaratkan dalam implementasi kebijakan sertifikasi guru di Kementerian Agama RI. Kondisi tersebut merupakan syarat yang menentukan apakah kebijakan sertifikasi guru melalui jalur PPG dalam Jabatan dapat diimplementasikan sesuai rencana atau tidak. Lingkungan strategis berperan penting bagi keberhasilan implementasi kebijakan terutama untuk tujuan-tujuan masa depan kebijakan dan keterlaksanaan kebijakan oleh pelaksana kebijakan. Aspek lingkungan strategis implementasi kebijakan sertifikasi guru melalui jalur PPG dalam Jabatan dapat menjadi kekuatan, kelemahan, peluang, dan tantangan dalam implementasi kebijakan sertifikasi guru.

Dalam lingkungan strategis kebijakan di Kementerian Agama RI ditemukan beberapa faktor yang dapat menjadi kekuatan implementasi kebijakan sertifikasi guru. Kekuatan-kekuatan tersebut yaitu: (1) Kejelasan tujuan kebijakan, (2) Kejelasan sasaran kebijakan, (3) Kejelasan landasan kebijakan, (4) Ketersediaan sarana dan prasarana, (5) Ketersediaan biaya.

Para pembuat dan pelaksanan kebijakan menyatakan bahwa tujuan implementasi kebijakan sertifikasi guru melalui jalur PPG dalam Jabatan dapat diketahui dengan jelas sebagaimana tercantum dalam regulasi dan petunjuk teknis pelaksanaan PPG dalam Jabatan.

Tujuan memberikan arah bagi implementasi suatu kebijakan. Tujuan akan menentukan bagaimana proses dan hasil implementasi kebijakan dilaksanakan. Tujuan yang jelas akan mengarahkan untuk merealisasikan rencana-rencana kebijakan sertifikasi guru melalui jalur PPG dalam Jabatan.

Tujuan kebijakan yang jelas merupakan hal yang penting sebagaimana dinyatakan Thomas R. Dye bahwa kebijakan adalah whatever governments choose to do or not to do. Governments do many thinks; they regulate conflict within society; they organize society to 
carry on conflict with other societies; they distribute a great variety of symbolic rewards and materials services to members of the society; and they extract money from society, most often in the form of taxes. Thus public policies may be regulative, organizational, distributive, or extractive - or all these things at once (Dye, 2005, p. 1). Dye mengatakan bahwa kebijakan merupakan apa saja yang dipilih oleh pemerintah untuk dilakukan atau tidak dilakukan. Kebijakan-kebijakan pemerintah dalam menangani persoalan-persoalan tersebut dapat bersifat regulatif, organisasional, distributif, atau semua sifat tersebut terkandung dalam suatu kebijakan.

Kebijakan sertifikasi guru melalui jalur PPG dalam Jabatan adalah kebijakan yang dikeluarkan oleh Kementerian Agama RI dengan tujuan utama mencetak guru profesional sesuai undang-undang dalam rangka memecahkan persoalan guru-guru yang masih belum tersertifikasi. Dalam kebijakan mengenai guru, Kementerian Agama RI menyusun peraturan perundangan dan program yang merupakan bentuk pelaksanaan dari kebijakan.

Tujuan kebijakan sertifikasi guru melalui jalur PPG dalam Jabatan yang telah ditetapkan oleh Kementerian Agama RI tersebut adalah dengan tujuan untuk meregulasi yang merupakan salah satu tujuan dari kebijakan publik (Nugroho, 2015, p. 60).

Beberapa kelemahan yang ditemukan dalam lingkungan strategis kebijakan sertifikasi guru di Kemenag RI yaitu: (1) rotasi kepemimpinan di tingkat Direktorat di lingkungan Direktur Jenderal Pendidikan Islam Kementerian Agama terjadi dalam kurun waktu yang cepat. Hal ini diakui menyebabkan kebijakan lama seringkali lambat ditindaklanjuti oleh pimpinan baru, (2) kurang koordinasi antar Direktorat di Kementerian Agama menyebabkan kendala dalam penerbitan NUPTK dan NRG. Direktorat Madrasah menyatakan bahwa hasil sertifikasi guru melalui jalur PPG dalam Jabatan yang telah dilaksanakan oleh Direktorat Pendidikan Tinggi Islam tidak langsung dilaporkan kepada Direktorat Madrasah sehingga ada keterlambatan dalam penerbitan NUPTK dan NRG untuk peserta sertifikasi guru melalui jalur PPG dalam Jabatan, (3) kurang koordinasi antara Kemenag dengan LPTK PTKI dengan indikasi adanya peserta mengundurkan diri karena kedapatan telah mengikuti PLPG, peserta masih mengajar di sekolah/madrasah, peserta tidak mendapatkan NIM/NPM sehingga sulit mengakses layanan di LPTK, belum ada rencana induk pengembangan PPG dalam Jabatan, belum ada evaluasi diri dan penjaminan mutu kelembagaan LPTK, LPTK tidak confident dengan output PPG, dan LPTK cenderung tunduk dengan keinginan peserta PPG.

Adapun peluang dalam implementasi kebijakan sertifikasi guru melalui jalur PPG dalam Jabatan yaitu kepercayaan diri peserta PPG dalam Jabatan yang meningkat jika dibanding dengan peserta sertifikasi guru yang mengikuti pola lain. Hal ini diungkapkan sendiri oleh peserta PPG dalam Jabatan. Direktur Pendidikan Tinggi Islam Prof. Dr. Dede Rosyada, MA menyatakan bahwa lulusan PPG dalam Jabatan bahkan menjadi narasumber (rujukan) di sekolahnya sendiri dan di daerahnya. Hal tersebut mengindikasikan bahwa implementasi kebijakan sertifikasi guru melalui jalur PPG dalam Jabatan telah memberikan kesempatan bagi peserta untuk meningkatkan kapasitas dan kompetensinya sebagai guru.

Dalam implementasi kebijakan sertifikasi guru melalui jalur PPG dalam Jabatan terdapat tantangan baik yang berasal dari dalam (internal) Kementerian Agama sendiri maupun yang berasal dari luar (eksternal) Kementerian Agama. Tantangan yang berasal dari internal Kementerian Agama adalah perubahan kebijakan. Salah satu faktor yang menyebabkan adanya perubahan kebijakan adalah rotasi kepemimpinan di lingkungan Direktorat Jenderal Pendidikan Islam Kementerian Agama. Selain itu perubahan kebijakan juga terjadi dari luar karena kebijakan di Kementerian Agama terkait bidang pendidikan harus merujuk pada kebijakan yang dikeluarkan oleh Kementerian Pendidikan dan Kebudayaan serta Kementerian Riset, Teknologi, dan Pendidikan Tinggi. 
Berdasarkan data empiris yang telah diuraikan dalam deskripsi kekuatan, kelemahan, peluang, dan tantangan sesuai aspek-aspek yang dievaluasi dalam komponen antecedents implementasi kebijakan sertifikasi guru melalui jalur PPG dalam Jabatan di Kementerian Agama, maka data tersebut dapat dianalisis lebih lanjut kesesuaiannya dengan kriteria evaluasi dan tujuan yang diinginkan (intents) dalam analisis kongruensi (congruence analysis)

Tujuan kebijakan berada pada kategori tinggi, terpenuhi, dan tersedia dengan jelas tujuan dari kebijakan sertifikasi guru melalui jalur PPG dalam Jabatan di Kementerian Agama. Sasaran kebijakan berada pada kategori moderat. Sasaran kebijakan sertifikasi guru melalui jalur PPG dalam Jabatan jelas dicantumkan namun tanpa target sehingga kurang mendukung pemenuhan target sertifikasi sesuai amanat UU Nomor 14 Tahun 2005 tentang Guru dan Dosen (Depdiknas, 2005) bahwa maksimal 10 tahun sejak diundangkan yaitu pada 2015 semua guru sudah tersertifikasi. Landasan kebijakan berada pada kategori moderat. Landasan implementasi kebijakan sertifikasi guru melalui jalur PPG dalam Jabatan secara runtut mengacu kepada seluruh regulasi mengenai sertifikasi guru namun dalam aturan yang lebih teknis Kemenag harus mengacu kepada aturan Kementerian Pendidikan dan Kebudayaan. Sarana dan prasarana kebijakan berada pada kategori tinggi. LPTK yang dinyatakan layak menjadi penyelenggara sertifikasi guru melalui jalur PPG dalam Jabatan memiliki sarana dan prasarana yang memadai. Biaya kebijakan berada pada kategori moderat. Terdapat biaya yang dianggarkan walau pun sesuai dengan kuota tidak banyak yang dapat dianggarkan oleh Kementerian Agama untuk melaksanakan kebijakan sertifikasi guru melalui jalur PPG dalam Jabatan. Selain itu besaran biaya PPG dalam Jabatan dianggap terlalu besar.

\section{Komponen Transactions}

Efektivitas proses implementasi kebijakan sertifikasi guru melalui jalur PPG dalam Jabatan di Kementerian Agama dievaluasi berdasarkan fungsi-fungsi manajemen. Dalam proses akreditasi, pelaksana kebijakan setidaknya dapat menerapkan fungsi-fungsi manajemen yaitu perencanaan, pengorganisasian, pengawasan, dan evaluasi hasil kinerja implementasi kebijakan sertifikasi guru.

Dengan demikian proses akreditasi meliputi proses untuk merencanakan, mengorganisir, memantau, dan mengevaluasi proses sertifikasi guru melalui jalur PPG dalam Jabatan.

Data penelitian menunjukkan bahwa sertifikasi guru melalui jalur PPG dalam Jabatan di Kementerian Agama tidak dicantumkan dalam Rencana Strategis Direktorat Jenderal Pendidikan Islam Kementerian Agama. Walau begitu PPG dalam Jabatan tetap direncanakan. Kementerian Agama sendiri membuat Pokja (Tim Task Force) Sertifikasi Guru.

Dalam perencanaan, Tim Task Force yang telah dibentuk menyusun panduan penyelenggaraan yang berisi seluruh rencana implementasi kebijakan sertifikasi guru melalui jalur PPG dalam Jabatan meliputi latar belakang, landasan hukum, tujuan, dan sasaran dari kebijakan sertifikasi guru melalui jalur PPG dalam Jabatan. Selain itu, aspek penyelenggaraan sertifikasi guru melalui jalur PPG dalam Jabatan adalah hal yang penting. Dalam rangka memastikan implementasi kebijakan sertifikasi guru yang terarah, Kementerian Agama menetapkan ruang lingkup dan sasaran kebijakan, persyaratan LPTK penyelenggara PPG dalam Jabatan, tugas LPTK, kualifikasi peserta, prosedur rekruitmen, kompetensi lulusan, proses pembelajaran, kurikulum PPG, kualifikasi dosen, PPL, uji kompetensi, dan penilaian. Semua rencana tersebut disusun dalam Panduan Penyelenggaraan Program Pendidikan Profesi Guru (PPG) dalam Jabatan di Lingkungan Kementerian Agama RI (Kementerian Agama RI, 2012).

Berkenaan dengan perencanaan kepesertaan, Direktorat Madrasah telah menetapkan data peserta sertifikasi guru pola PLPG. Data peserta tersebut diberikan kepada Direktorat Pendidikan Tinggi Islam dengan harapan dapat diambil sebagiannya untuk ditetapkan sebagai peserta PPG da- 
lam Jabatan. Dari data peserta tersebut DIKTIS telah menetapkan peserta yang dapat mengikuti sertifikasi guru melalui jalur PPG dalam Jabatan.

Walaupun Kementerian Agama sudah menetapkan rambu-rambu dan pola rekrutmen dengan begitu rinci, dalam implementasi kebijakan sertifikasi guru melalui jalur PPG dalam Jabatan di Kementerian Agama tidak terlepas dari persoalan. Banyak peserta yang mengundurkan diri dari program PPG. Pada angkatan 2013/2014 (angkatan kedua) terdapat 2 orang peserta guru PNS dan 42 orang peserta non PNS yang mengundurkan diri. Pengunduran diri tersebut disebabkan oleh, salah satunya, yang bersangkutan kedapatan telah mengikuti PLPG. Padahal salah satu syarat yang harus dipenuhi oleh calon peserta program PPG adalah belum pernah ikut sertifikasi guru (lulus atau tidak lulus) baik melalui penilaian portofolio (PF), PLPG, ataupun PPG.

Selain peserta yang mengundurkan diri, terdapat pula peserta yang masih melakukan aktivitas pembelajaran di sekolah atau madrasah tempat mengajar selama mengikuti program PPG. Padahal selama mengikuti program, peserta PPG harus bebas tugas dari semua kewajiban mengajar di satuan administrasi pangkal (satminkal) tempat yang bersangkutan menjadi Guru Tetap. Peserta PPG harus kembali mengabdi di tempat tugas semula setelah menyelesaikan program. Oleh karena itu, selama mengikuti program peserta PPG diberikan bantuan pendidikan dan biaya hidup (living cost).

Masih berkenaan dengan kepesertaan, beberapa peserta program PPG di beberapa LPTK tidak lulus karena terkendala sulitnya mendapatkan SK dari sekolah dan madrasah tempat mengajar serta Dinas Pendidikan Kabupaten/Kotamadya.

Permasalahan mengenai kepesertaan juga terdapat pada Nomor Induk Mahasiswa (NIM) yang tidak didapatkan oleh calon peserta yang dinyatakan lulus dan diterima dalam program PPG. Tidak didapatkannya NIM oleh peserta program PPG mengakibatkan adanya kesulitan-kesulitan yang dialami peserta dalam mengakses fasilitas yang dimiliki oleh LPTK.

Pada saat penerbitan Nomor Registrasi Guru (NRG), peserta program PPG yang telah lulus tidak serta merta langsung mendapatkan NRG. Penerbitan NRG yang mengalami keterlambatan berakibat pada keterlambatan verifikasi data yang berujung pada terlambatnya pembayaran tunjangan sertifikasi. Kementerian Agama perlu segera membenahi sistem Nomor Unik Pendidik dan Tenaga Kependidikan (NUPTK) dan NRG. Padahal, dalam verifikasi dua hal tersebut yang dibutuhkan. Sementara di lapangan, banyak guru madrasah yang belum memiliki NRG meski telah lulus sertifikasi.

Beberapa persoalan lain seperti belum adanya rencana induk pengembangan program PPG yang disusun bersama oleh LPTK dan pemerintah dan belum adanya evaluasi diri dan penjaminan mutu kelembagaan LPTK sebagai penyelenggara program PPG.

Direktur Pendidikan Tinggi Islam Kementerian Agama sendiri mengakui jika masih ada beberapa kendala yang terdapat dalam penyelenggaraan program PPG dalam Jabatan antara lain: (1) LPTK yang tidak confident dengan output PPG, (2) LPTK yang cenderung tunduk pada keinginan peserta PPG, (3) peserta PPG mengundurkan diri, (4) keterlambatan penerbitan SK NRG, dan (5) kebijakan yang kurang berpihak.

Kementerian Agama melakukan proses pengawasan implementasi kebijakan sertifikasi guru melalui jalur PPG dalam Jabatan melalui upaya monitoring dan evaluasi (monev). Monev dilaksanakan pada akhir tahun pelaksanaan PPG dalam Jabatan dengan menggunakan instrumen yang disusun oleh Direktorat Pendidikan Tinggi Islam Kementerian Agama. Instrumen monev terdiri dari (1) instrumen monev untuk pengelola, (2) instrumen monev untuk dosen, dan (3) instrumen monev untuk mahasiswa (peserta PPG dalam Jabatan).

Monitoring dan evaluasi Program PPG merupakan rangkaian kegiatan pemantauan, pengkajian/analisis, pengendalian dan 
pelaporan yang diperlukan untuk mengetahui kemajuan hasil yang telah dicapai dan permasalahan yang dihadapi dalam pelaksanaannya, serta mencari solusi yang tepat untuk mengatasi permasalahan tersebut. Monitoring dan evaluasi ini penting juga dilaksanakan agar penyelenggaraan Program PPG tidak keluar dari rambu-rambu yang telah ditetapkan dan untuk mengukur kinerja para pelaksana program dalam pencapaian sasaran kegiatan secara efektif sesuai dengan tujuan yang telah dicanangkan.

Selain pengawasan terhadap implementasi sertifikasi guru melalui jalur PPG dalam Jabatan dalam bentuk monev di akhir pelaksanaan program, Direktorat Pendidikan Tinggi Islam juga melaksanakan evaluasi diri (assesment) terhadap LPTK sebagai penyelenggara PPG dalam jabatan. Assesment dilaksanakan pada saat Rapat Koordinasi PPG dalam Jabatan yang dihelat pada akhir pelaksanaan program. Direktorat Pendidikan Tinggi Islam Kementerian Agama menyusun instrumen assesment yang diberikan kepada LPTK PTKI penyelenggara PPG dalam Jabatan.

Data pada komponen evaluasi proses implementasi kebijakan (transactions) sertifikasi guru melalui jalur PPG dalam Jabatan, maka hasil temuan di lapangan dapat dianalisis, dirangkum, dan ditampilkan dengan analisis kongruensi komponen transactions.

Perencanaan berada pada kategori moderat. Kementerian Agama menyusun perencanaan kebijakan sertifikasi guru melalui jalur pendidikan berdasarkan pada regulasi walaupun perencanaan tersebut tidak tercantum dalam Renstra. Pengorganisasian berada pada kategori moderat. Kementerian agama berupaya melaksanakan kebijakan sertifikasi guru melalui jalur PPG dalam Jabatan dengan mengacu kepada perencanaan. Namun dalam implementasi masih terdapat persoalan yang dihadapi LPTK PTKI. Pengawasan berada pada kategori moderat. Terdapat pengawasan dalam bentuk monitoring dan evaluasi (monev) terhadap implementasi kebijakan namun hasil monev tidak diolah dan disusun untuk dijadikan rekomendasi per- baikan implementasi kebijakan. Evaluasi berada pada kategori moderat. Kementerian Agama melakukan upaya evaluasi dalam bentuk assesment terhadap LPTK PTKI yang telah melaksanakan sertifikasi guru melalui jalur PPG dalam Jabatan dan juga evaluasi yang dilakukan oleh Pokja. Namun hasil evaluasi kurang terdokumentasikan dalam suatu bentuk hasil evaluasi yang dapat dijadikan rekomendasi perbaikan kebijakan.

Dari hasil evaluasi kebijakan sertifikasi guru melalui jalur PPG dalam Jabatan di Kementerian Agama didapati proses kebijakan yang senada dengan proses yang dikemukakan para ahli kebijakan seperti Willian N. Dunn, David Easton, Anderson, Patton dan Savicky yang dirangkum oleh Riant Nugroho bahwa proses kebijakan dimulai dari gagaran kebijakan, formulasi kebijakan, implementasi dan kinerja kebijakan (Nugroho, 2008, p. 347). Adapun model formulasi kebijakan dalam implementasi kebijakan sertifikasi guru melalui jalur PPG dalam Jabatan adalah model kelembagaan (institusional) di mana Kementerian Agama RI mengemban tugas untuk membuat kebijakan. Kementerian Agama RI adalah institusi legal untuk menyusun kebijakan publik dan mempunyai wewenang serta legitimasi untuk menegakkan kebijakan sertifikasi guru di lingkungan Kemenag RI.

Persoalan dan kendala yang dihadapi lebih banyak pada informasi yang kurang memadai, koordinasi antar institusi, dan sosialisasi program. Hal ini senada dengan hasil penelitian yang dilakukan oleh Hastuti (Utami, 2015, pp. 471-481).

\section{Komponen Outcomes}

Tahap terakhir dari evaluasi implementasi kebijakan sertifikasi guru melalui jalur PPG dalam Jabatan di Kementerian Agama dengan model evaluasi Countenance yang dikembangkan Stake adalah evaluasi terhadap komponen hasil (outcomes).

Sertifikasi guru melalui jalur PPG dalam Jabatan di Kementerian Agama telah dilaksanakan sebanyak 2 kali. Saat pertama kali dilaksanakan Kementerian Pendidikan dan Kebudayaan telah menetapkan seba- 
nyak 24 LPTK di bawah Kementerian Agama yang dinyatakan layak melaksanakan sertifikasi guru melalui jalur PPG dalam Jabatan. Dari jumlah tersebut, Kementerian Agama melakukan screening ulang dengan juga mempertimbangkan jumlah kuota dan kesiapan LPTK sehingga pada 2012 melalui Surat Keputusan Direktur Jenderal Pendidikan Islam Nomor 1909 Tahun 2012 tentang Penetapan Perguruan Tinggi Agama Islam (PTAI) Penyelenggara Program Pendidikan Profesi Guru (PPG) Bagi Guru RA/Madrasah dan Kuota Masing-Masing Tahun 2012 ditetapkan jumlah LPTK yang siap sebanyak 18 LPTK. Pada 2013 melalui Surat Keputusan Direktur Jenderal Pendidikan Islam Nomor 2090 Tahun 2013 tentang Penetapan Kuota Peserta Pendidikan Profesi Guru dalam Jabatan Tahun Anggaran 2013 juga ditetapkan LPTK yang layak menyelenggarakan sertifikasi guru melalui jalur PPG dalam jabatan sebanyak 18 LPTK. Dari 18 LPTK yang telah ditetapkan oleh Direktorat Jenderal Pendidikan Islam Kementerian Agama ditetapkan lagi 12 LPTK yang dinyatakan siap menyelenggarakan PPG dalam Jabatan.

Berdasarkan keseluruhan uraian deskriptif mengenai hasil dari implementasi kebijakan sertifikasi guru melalui jalur PPG dalam Jabatan di Kementerian Agama, maka kondisi objektif tersebut dapat dianalisis dan dirangkum dengan analisis kongruensi komponen hasil (outcomes).

Hasil Berada pada posisi moderat. Implementasi kebijakan sertifikasi guru melalui jalur PPG dalam Jabatan di Kementerian Agama menghasilkan lulusan guru profesional. Namun masih terdapat beberapa persoalan dalam implementasi yang menyebabkan banyakya peserta PPG dalam Jabatan yang mengundurkan diri dan beberapa lagi tidak lulus.

Perbaikan berkelanjutan berada pada kategori moderat. Kementerian Agama bersama dengan LPTK berkomitmen untuk tetap melanjutkan sertifikasi guru melalui jalur PPG dalam Jabatan. Namun kebijakan PPG dalam Jabatan di tahun ketiga terhenti karena anggaran dialihkan untuk PLPG, izin penyelenggaraan PPG dalam Jabatan untuk LPTK PTKI habis, menunggu payung hukum dari Kementerian Pendidikan dan Kebudayaan. Komitmen perbaikan tersebut diwujudkan dalam penyusunan desain PPG Pra Jabatan dengan mengacu kepada pengalaman melaksanakan PPG dalam Jabatan.

Data hasil evaluasi terhadap implementasi kebijakan sertifikasi guru melalui jalur PPG dalam Jabatan di Kementerian Agama menunjukkan adanya keterkaitan antara komponen antecedents, transactions, dan outcomes. Data empiris memperlihatkan adanya kontingensi antara kondisi awal, proses, dan hasil implementasi kebijakan sertifikasi guru melalui jalur PPG dalam Jabatan di Kementerian Agama. Kontingensi tersebut terlihat pada tujuan (intents), data (observations), serta keterkaitannya dengan tingkat efektivitas (judgements) dari setiap komponen tersebut. Ketika kondisi awal lingkungan strategis implementasi kebijakan sertifikasi guru melalui jalur PPG dalam Jabatan berada pada kategori moderat, ternyata proses implementasi pun berada pada kategori moderat bahkan cenderung rendah. Demikian pula hasil implementasi kebijakan berada pada posisi moderat cenderung rendah. Hal ini menunjukkan adanya aspek yang saling berhubungan dan menentukan keterlaksanaan kebijakan.

\section{Simpulan}

Berdasarkan uraian hasil penelitian dan pembahasan dapat disampaikan simpulan sebagi berikut. Kondisi awal lingkungan strategis implementasi kebijakan sertifikasi guru melalui jalur PPG dalam Jabatan di Kementerian Agama RI cukup mendukung keterlaksanaan dan pencapaian hasil kebijakan walaupun masih ditemui beberapa kelemahan dan kendala. Beberapa kelemahan tersebut yaitu landasan kebijakan yang harus selalu mengacu kepada Kementerian Pendidikan dan Kebudayaan menyebabkan Kementerian Agama lambat dalam menentukan keberlanjutan kebijakan dan atau merespon persoalan di lapangan yang membutuhkan kebijakan. Sasaran kebijakan yang telah ditentukan tidak dite- 
tapkan targetnya sehingga implementasi kebijakan kurang mendukung pencapaian target sertifikasi guru secara nasional. Biaya yang dibutuhkan dalam implementasi kebijakan memadai namun masih belum dapat mengakomodir peserta sertifikasi guru dalam jumlah yang banyak. Hal ini disadari karena biaya yang dibutuhkan sangat besar. Adapun beberapa kendala yaitu rotasi kepemimpinan di tingkat Direktorat, kurang koordinasi antar Direktorat di Kementerian Agama, dan kurangnya koordinasi antara Kemenag dengan LPTK PTKI.

Proses implementasi kebijakan sertifikasi guru melalui jalur PPG dalam Jabatan di Kementerian Agama RI secara umum sudah dilaksanakan dengan baik. Namun perencanaan kebijakan tidak tercantum dalam Rencana Strategis (Renstra) Direktorat Jenderal Pendidikan Islam Kementerian Agama RI. Hal ini ditengarai menyebabkan kebijakan sertifikasi guru melalui jalur PPG dalam Jabatan kurang menjadi prioritas. Pengorganisasian implementasi kebijakan sudah diupayakan untuk selalu mengacu kepada regulasi dan panduan penyelenggaran PPG dalam Jabatan. Namun dalam pelaksanaan masih ditemui beberapa kendala yaitu peserta mengundurkan diri karena kedapatan telah mengikuti PLPG, peserta masih mengajar di sekolah/madrasah, peserta tidak mendapatkan NIM/NPM sehingga sulit mengakses layanan di LPTK, belum ada rencana induk pengembangan PPG dalam Jabatan, belum ada evaluasi diri dan penjaminan mutu kelembagaan LPTK, LPTK tidak confident dengan output PPG, dan LPTK cenderung tunduk dengan keinginan peserta PPG. Kementerian Agama RI melakukan proses pengawasan dan evaluasi terhadap implementasi kebijakan sertifikasi guru melalui jalur PPG dalam Jabatan. Namun hasil pengawasan dan evaluasi tersebut kurang terdokumentasikan sehingga proses tindak lanjut tidak dilaksanakan.

Implementasi kebijakan sertifikasi guru melalui jalur PPG dalam Jabatan di Kementerian Agama RI menunjukkan hasil lulusan guru profesional walaupun dalam pelaksanaan masih terdapat kelemahan dan kendala yang menyebabkan banyaknya peserta yang mengundurkan diri dan tidak lulus. Pada angkatan I seluruh peserta sertifikasi guru melalui jalur PPG dalam Jabatan di Kementerian Agama RI lulus semua. Pada angkatan II dari 947 peserta jumlah yang lulus sebanyak 945 (99,79\%) dan yang tidak lulus sebanyak $2(0,21 \%)$. Berdasarkan pengalaman menyelenggarakan kebijakan sertifikasi guru melalui jalur PPG dalam Jabatan, Kementerian Agama RI bersama dengan LPTK berkomitmen untuk tetap melanjutkan sertifikasi guru melalui jalur PPG dalam Jabatan. Namun kebijakan PPG dalam Jabatan di tahun ketiga terhenti karena anggaran dialihkan untuk PLPG, izin penyelenggaraan PPG dalam Jabatan untuk LPTK PTKI habis, dan menunggu payung hukum dari Kementerian Pendidikan dan Kebudayaan. Komitmen perbaikan tersebut diwujudkan dalam penyusunan desain PPG Pra Jabatan dengan mengacu kepada pengalaman melaksanakan PPG dalam Jabatan.

\section{Daftar Pustaka}

Badruzzaman, B. (2016). The Impact of teacher certification on the improvement of education quality in madrasah. Jurnal Al Qalam, 22(1).

Crabb, A., \& Leroy, P. (2008). The handbook of environmental policy evaluation. London: Earthscan.

Creswell, J. W. (2008). Research design. Yogyakarta: Pustaka Pelajar.

Depdiknas. Undang-Undang No. 14 Tahun 2005 tentang Guru dan Dosen (2005). Jakarta.

Dye, T. R. (2005). Understanding public policy. New Jersey: Pearson Education Inc.

Kementerian Agama RI. (2012). Panduan penyelenggaraan program pendidikan profesi guru (PPG) dalam jabatan di lingkungan Kementerian Agama RI. 2015. Jakarta: Direktorat Pendidikan Tinggi Islam Direktorat Jenderal Pendidikan Islam Kementerian 
Agama RI.

Kusumawardhani, P. N. (2017). Does certification program lead to better quality teachers?. evidence from Indonesia. Education Economics, 25(6).

Nugroho, R. (2008). Public policy. Jakarta: Elexmedia Komputindo.

Nugroho, R. (2015). Kebijakan publik di negara-negara berkembang. Yogyakarta: Pustaka Pelajar.

Qowaid, Q. (2015). Pengaruh sertifikasi guru terhadap peningkatan kinerja guru PAI di SMP dan MTs. Edukasi Jurnal Penelitian Pendidikan Agama Dan Keagamaan, 13(3). Retrieved from http://jurnaledukasikemenag.org/in dex.php/edukasi/article/view/251

Utami, I. L. P. (2015). Teacher certification program in Indonesia: problems and recommendation for the betterment of the program. International Journal of English and Education, 4(2), 471-481.

Yusuf, N. F., Bekti, H., \& Sukarno, D. (2017). Implementasi program sertifikasi guru dalam jabatan (studi pada Madrasah Aliyah negeri Ciparay Kabupaten Bandung). JANE - Jurnal Administrasi Negara, 2(1). https:// doi.org/10.24198/jane.v2i1.13 682 